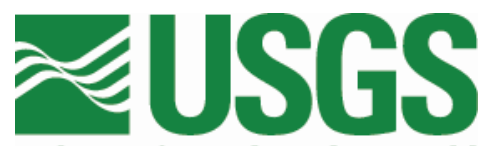

science for a changing world

\title{
Spatial databases of the Humboldt Basin mineral resource assessment, northern Nevada
}

By Mark J. Mihalasky and Lorre A. Moyer

\section{U.S. Geological Survey Open-File Report 2004-1245}




\section{Table of Contents}

Abstract

\section{List of Figures}

Figure 1. Location of northern Nevada tract map assessment area (shaded) and the Humboldt River Basin (stippled).................................................................... 4

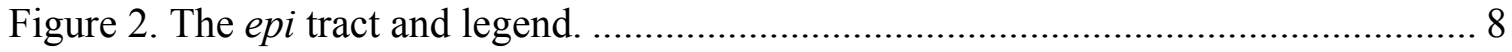

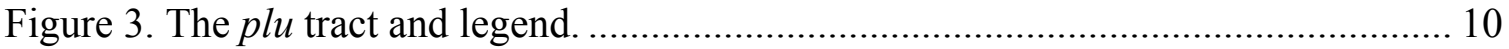

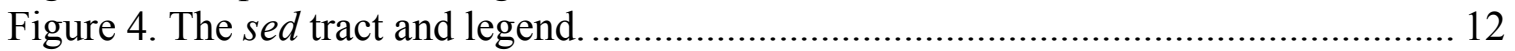

\section{List of Tables}

Table 1. List of spatial database and metadata files provided in this publication ............ 6

Table 2. Attributes and descriptions for the EPI grid with appended WofE.dbf .............. 7

Table 3. Attributes and descriptions for the PLU grid with appended WofE.dbf ............ 9

Table 4. Attributes and descriptions for the SED grid with appended WofE.dbf .......... 11

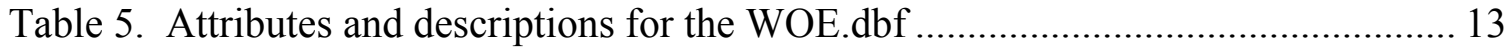

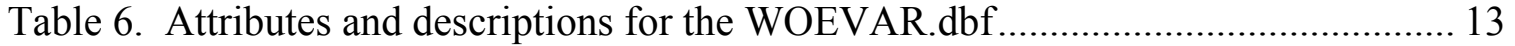

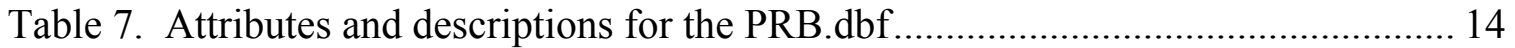

Table 8. Attributes and descriptions for the LRCOEF.dbf ......................................... 14 


\section{Abstract}

This report describes the origin, generation, and format of tract map databases for deposit types that accompany the metallic mineral resource assessment for the Humboldt River Basin, northern Nevada, (Wallace and others, 2004, Chapter 2). The deposit types include pluton-related polymetallic, sedimentary rock-hosted $\mathrm{Au}-\mathrm{Ag}$, and epithermal AuAg. The tract maps constitute only part of the assessment, which also includes new research and data for northern Nevada, discussions on land classification, and interpretation of the assessment maps. The purpose of the assessment was to identify areas that may have a greater favorability for undiscovered metallic mineral deposits, provide analysis of the mineral-resource favorability, and present the assessment of the Humboldt River basin and adjacent areas in a digital format using a Geographic Information System (GIS).

\section{Introduction}

In 1996, the U.S. Geological Survey (USGS) began a GIS-based mineral resource assessment of pluton-related polymetallic, sedimentary rock-hosted $\mathrm{Au}-\mathrm{Ag}$, epithermal $\mathrm{Au}-\mathrm{Ag}$ deposits for Nevada. The assessment was carried out for all of northern Nevada north of 38.5 degrees latitude, but it focused specifically on the Humboldt River Basin (fig. 1). Completed in 2002, the assessment includes three GIS mineral-resource assessment tract maps: plu, sed and epi. A "mineral-resource assessment tract" is a geographic region (a tract of land) that has been determined to possess geologic attributes characteristic of a particular type of mineral deposit.

The Humboldt Mineral-Resource Assessment Team delineated "non-permissive," "permissive," "favorable," and "prospective" assessment attributes using a combination of expert knowledge, digital data analyses, and modeling techniques. See Mihalasky and Wallace (2004) for an explanation of these attributes. Expert knowledge was used to (1) create, select, and appraise datasets, (2) delineate permissive and non-permissive assessment tracts, and (3) evaluate as well as revise preliminary mineral-resource assessment maps derived from data-driven modeling. Both the expert and data-driven components of the assessment were conducted using data that ranged in scale from $1: 250,000$ to about 1:1,000,000. Manipulation and combination of the data has further decreased the resolution and accuracy to approximately 1:1,000,000. The ground resolution of the assessment tract map is about $2 \mathrm{~km}$.

\section{Acknowledgments}

The authors appreciate the assistance of the U.S. Geological Survey's Humboldt MineralResource Assessment Team and Western Region Mineral Resources Team including A.R. Wallace, S. Ludington, S.G. Peters, T.G. Theodore, D.A. Ponce, D.A. John, B.R. Berger, M.L. Zientek, G.B. Sidder, and R.A. Zierenberg. Gary Raines of the U.S. Geological Survey's Reno Field Office provided guidance on modeling methodology throughout the course of the assessment. 


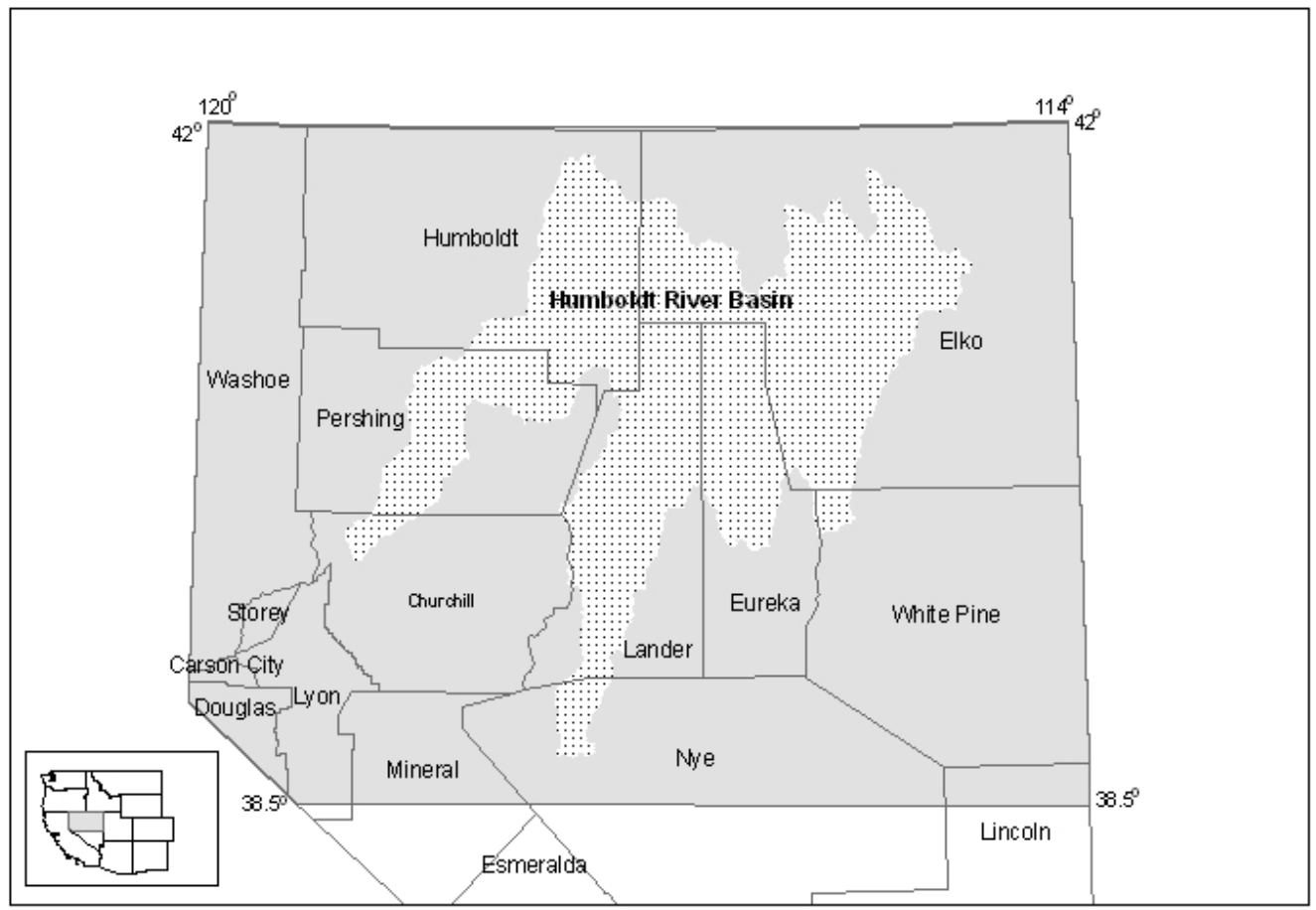

Figure 1. Location of northern Nevada tract map assessment area (shaded) and the Humboldt River Basin (stippled). 


\section{Overview of Data Files}

The mineral-resource assessment tract maps are provided in raster format as ESRI integer grid files downloadable from the website $\leq$ http://pubs.usgs.gov/of/2004/1245>. The tract maps were generated by integrating multiple geoscientific maps using the modeling techniques weights of evidence (WofE) and weighted logistic regression (WLR). Modeling was carried out with ESRI's ArcView 3.3 extension "Arc-SDM" (Spatial Data Modeller), developed by the U.S. Geological Survey and the Geological Survey of Canada (Kemp and others, 2001).

WofE and WLR are empirical, data-driven methodologies for integrating spatial data patterns and building predictive models (Bonham-Carter, 1994). They use (1) conditional probabilities to measure the spatial association between point-objects and patterns, and (2) Bayes' probability theorem (WofE) or logistic regression (WLR) to mathematically integrate patterns in order to predict the distribution of point-objects. WofE and WLR models are expressed in the form of a single "favorability map" of posterior probability. The favorability maps for this assessment integrate the spatial distribution of training sites (point-objects representing known mineral sites) and evidence maps (geoscientific phenomena related to mineralizing systems) to predict the probable distribution of yet unidentified sites.

The training sites used to identify and weight the importance of evidence maps were known mineral sites possessing the characteristics common to a particular deposit type. Training sites are regarded as binary - either present or absent, and it is presumed that their location and presence enable prediction of the particular deposit type under consideration. Evidence maps are typically multi-class and can include geological map units and structure, geochemical and geophysical anomalies, remotely sensed images and other earth-observation data, and even conceptual or interpretive maps. In order to facilitate the integration process, the evidence maps are usually reduced to "predictor maps." Predictor maps consist of predictor patterns, typically binary- or ternary-class, where the spatial association between the training sites and an evidence map is optimized. The predictor maps collectively constitute "layers of evidence."

For this assessment, WofE was used to analyze the bivariate spatial associations between the training sites and the various evidence maps, and WLR was used to integrate (combine) the evidence maps and delineate the prospective and favorable assessment tracts. In some cases, the evidence maps selected by the assessment team had a high conditional dependence (mutually interrelated). By using WLR to combine the maps, bias caused by conditional dependency was avoided. The non-permissive and permissive tract boundary was delineated using a previous knowledge-driven assessment for Nevada (Cox and others, 1996) because the evidence maps available did not allow for a reliable data-driven estimation.

Assessment tract map grids, associated tables, and metadata are provided in several files that are listed and briefly described in table 1 . The metadata files provide very detailed descriptions of the spatial data in a formal format defined by the Federal Geographic Data 
Committee (FGDC). Metadata include data sources (lineage), data resolution (horizontal accuracy), data processing procedures, items (fields) in the databases, definitions of terminology used in populating the databases, and map projection information. The ESRI interchange-format files for the spatial databases must be imported prior to viewing or using the databases. Compressed symbolization files are provided for consistent viewing of the tracts in ArcMap or ArcView.

Table 1. List of spatial database and metadata files provided in this publication

\begin{tabular}{|c|c|}
\hline File Name & File Description \\
\hline \multicolumn{2}{|r|}{ Formal Metadata } \\
\hline epi-html.htm & $\begin{array}{l}\text { A file that describes and documents data used in the epithermal } \\
\text { tract grid (epi) in Federal Geographic Data Committee } \\
\text { "hypertext markup language" (FGDC HTML) format (also } \\
\text { known as a parseable text format). }\end{array}$ \\
\hline epi-FAQ.htm & $\begin{array}{l}\text { A file that describes and documents data used in the epithermal } \\
\text { tract grid (epi) in Federal Geographic Data Committee } \\
\text { "frequently asked questions" (FGDC FAQ) format. }\end{array}$ \\
\hline plu-html.htm & $\begin{array}{l}\text { A file that describes and documents data used in the pluton tract } \\
\text { grid }(p l u) \text { in FGDC HTML format. }\end{array}$ \\
\hline plu-FAQ.htm & $\begin{array}{l}\text { A file that describes and documents data used in the pluton tract } \\
\text { grid }(p l u) \text { in FGDC FAQ format. }\end{array}$ \\
\hline sed-html.htm & $\begin{array}{l}\text { A file that describes and documents data used in the sedimentary } \\
\text { tract grid }(\text { sed }) \text { in FGDC HTML format. }\end{array}$ \\
\hline sed-FAQ.htm & $\begin{array}{l}\text { A file that describes and documents data used in the sedimentary } \\
\text { tract grid (sed) in FGDC FAQ format. }\end{array}$ \\
\hline \multicolumn{2}{|r|}{ Spatial Databases } \\
\hline epi.e00 & An ESRI interchange-format file for epithermal tract data. \\
\hline plu.e00 & An ESRI interchange-format file for pluton tract data. \\
\hline sed.e00 & An ESRI interchange-format file for sedimentary tract data. \\
\hline \multicolumn{2}{|r|}{ Symbolization Files } \\
\hline symbolization.zip & $\begin{array}{l}\text { A collection of compressed symbolization files including Arc } \\
\text { Grid color map files (.clr), ArcMap layer files (.lyr) and } \\
\text { ArcView legend files (.avl) that can be used to symbolize the } \\
\text { epi, plu and sed tract data. }\end{array}$ \\
\hline
\end{tabular}




\section{Spatial Databases}

\section{EPI}

Attributes of the ESRI raster grid for the epithermal Au-Ag metallic mineral-resource assessment tract, epi, are displayed in table 2. WofE.dbf was created from Arc-SDM and appended to the grid table. The epi tract and legend are displayed in figure 2.

Table 2. Attributes and descriptions for the EPI grid with appended WofE.dbf

\begin{tabular}{|c|c|}
\hline Attribute & Attribute Description \\
\hline VALUE & Object ID. The internal feature number. \\
\hline COUNT & The count of grid cells with a particular value. \\
\hline ASFREQ & Presence or absence of predictor pattern arsenic anomaly. \\
\hline EPILITH & Presence or absence of predictor pattern epithermal-lithologic units. \\
\hline MAGTRRN & Presence or absence of predictor pattern magnetic terranes. \\
\hline AREA_SQM & $\begin{array}{l}\text { Arc-SDM calculation of area in meters squares of the unique } \\
\text { condition overlap. }\end{array}$ \\
\hline TRNGPOINTS & $\begin{array}{l}\text { Number of mineral training sites that fall within the unique condition } \\
\text { overlap. }\end{array}$ \\
\hline POST_PROB & $\begin{array}{l}\text { Posterior probability (the posterior logit converted to a probability), } \\
\text { calculated using Bayes' Rule. }\end{array}$ \\
\hline PSTPRBNRM & Normalized posterior probability. \\
\hline POST_LOGIT & Posterior logit (the sum of weights added to the prior logit). \\
\hline SUM_WEIGHT & $\begin{array}{l}\text { The sum of the weights }(\mathrm{W}+\text { and } \mathrm{W}-) \text { for each evidence map class } \\
\text { occurring in the unique condition. }\end{array}$ \\
\hline UNCERTAINT & $\begin{array}{l}\text { The uncertainty due to the calculation of weights (standard } \\
\text { deviation). }\end{array}$ \\
\hline MSNG_DATA & The uncertainty due to missing data (standard deviation). \\
\hline TOT_UNCRTY & $\begin{array}{l}\text { The combined uncertainty due to weights and due to missing data } \\
\text { (standard deviation). }\end{array}$ \\
\hline LRPOSTPROB & Posterior probability calculated using logistic regression. \\
\hline LRTVALUE & Logistic regression posterior probability Studentized-T value. \\
\hline LR_STD_DEV & Logistic regression posterior probability standard deviation. \\
\hline TRACT & $\begin{array}{l}\text { Mineral-resource assessment tract = nonpermissive, permissive, } \\
\text { favorable or prospective. }\end{array}$ \\
\hline
\end{tabular}




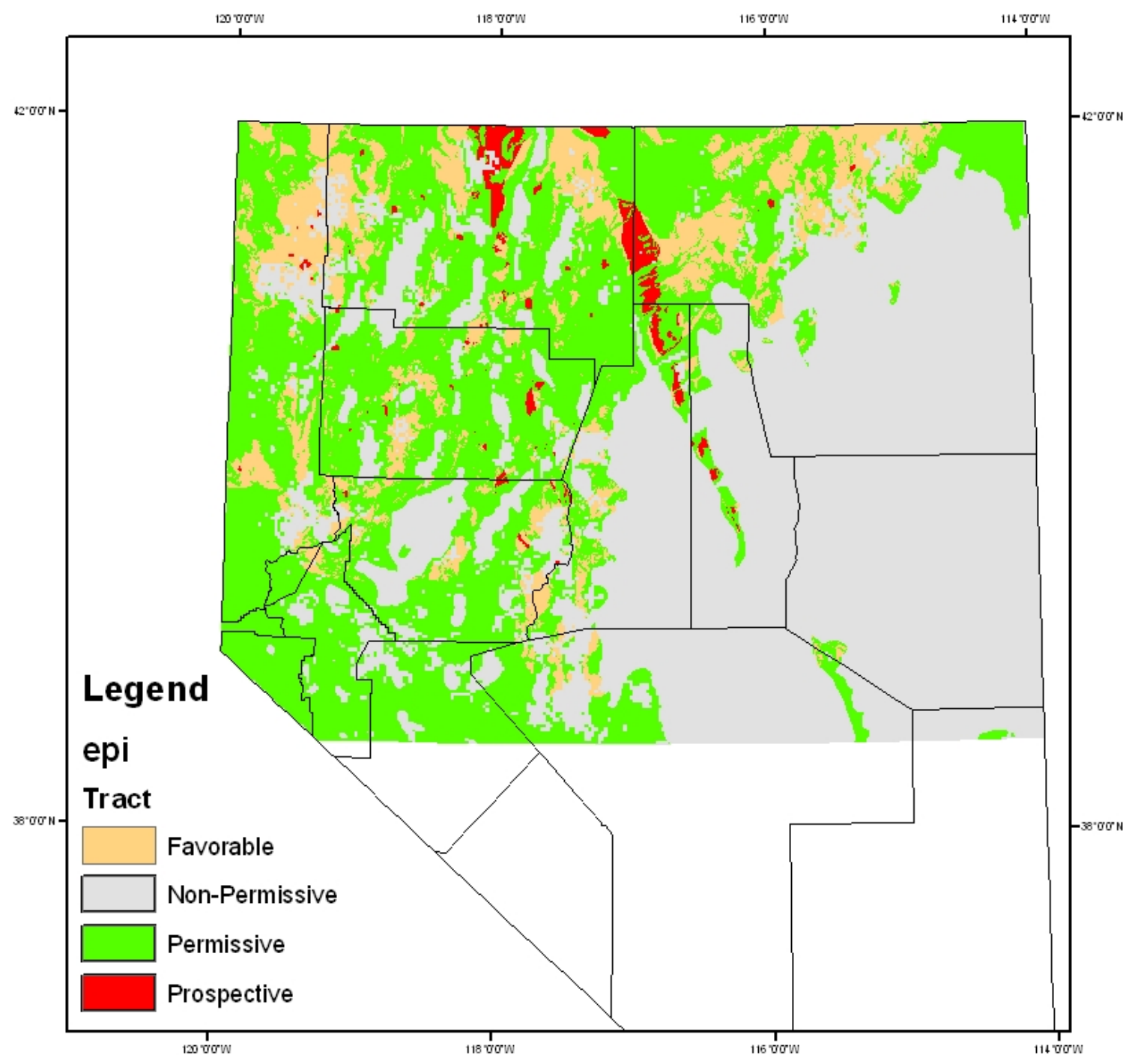

Figure 2. The epi tract and legend for epithermal Au-Ag deposits. 


\section{$P L U$}

Attributes of the ESRI raster grid for the pluton-related metallic mineral-resource assessment tract map, plu, are displayed in table 3. WofE.dbf was created from ArcSDM and appended to the grid table. The plu tract and legend are displayed in figure 3.

Table 3. Attributes and descriptions for the PLU grid with appended WofE.dbf

\begin{tabular}{|c|c|}
\hline Attribute & Attribute Description \\
\hline VALUE & Object ID. The internal feature number. \\
\hline COUNT & The count of grid cells with a particular value. \\
\hline ASFREQ & Presence or absence of predictor pattern arsenic anomaly. \\
\hline CU_PB_ZN & Presence or absence of predictor pattern $\mathrm{Cu}-\mathrm{Pb}-\mathrm{Zn}$ anomaly. \\
\hline GRVBSHI & $\begin{array}{l}\text { Presence or absence of predictor pattern basement gravity terranes, } \\
\text { reflecting regions of similar anomaly features or geophysical fabric. }\end{array}$ \\
\hline GVBSLF & $\begin{array}{l}\text { Presence or absence of predictor pattern basement gravity lineaments, } \\
\text { reflecting abrupt lateral variations in the density of basement rocks. }\end{array}$ \\
\hline LITHODVR & $\begin{array}{l}\text { Presence or absence of predictor pattern lithodiversity of the geologic } \\
\text { map of Nevada. }\end{array}$ \\
\hline PLUTONS & $\begin{array}{l}\text { Presence or absence of predictor pattern proximity to plutonic rocks } \\
\text { represented on the geologic map of Nevada. }\end{array}$ \\
\hline SKARNS & $\begin{array}{l}\text { Presence or absence of predictor pattern proximity to Mineral } \\
\text { Resources Data System (MRDS) skarn deposits. }\end{array}$ \\
\hline AREA_SQM & $\begin{array}{l}\text { Arc-SDM calculation of area in meters squares of the unique } \\
\text { condition overlap. }\end{array}$ \\
\hline TRNGPOINTS & $\begin{array}{l}\text { Number of mineral training sites that fall within the unique condition } \\
\text { overlap. }\end{array}$ \\
\hline POST_PROB & $\begin{array}{l}\text { Posterior probability (the posterior logit converted to a probability), } \\
\text { calculated using Bayes' Rule. }\end{array}$ \\
\hline PSTPRBNRM & Normalized posterior probability. \\
\hline POST_LOGIT & Posterior logit (the sum of weights added to the prior logit). \\
\hline SUM_WEIGHT & $\begin{array}{l}\text { The sum of the weights (W+ and W-) for each evidence map class } \\
\text { occurring in the unique condition. }\end{array}$ \\
\hline UNCERTAINT & $\begin{array}{l}\text { The uncertainty due to the calculation of weights (standard } \\
\text { deviation). }\end{array}$ \\
\hline MSNG_DATA & The uncertainty due to missing data (standard deviation). \\
\hline TOT_UNCRTY & $\begin{array}{l}\text { The combined uncertainty due to weights and due to missing data } \\
\text { (standard deviation). }\end{array}$ \\
\hline LRPOSTPROB & Posterior probability calculated using logistic regression. \\
\hline LRTVALUE & Logistic regression posterior probability Studentized-T value. \\
\hline LR_STD_DEV & Logistic regression posterior probability standard deviation. \\
\hline TRACT & $\begin{array}{l}\text { Mineral-resource assessment tract = nonpermissive, permissive, } \\
\text { favorable or prospective. }\end{array}$ \\
\hline
\end{tabular}




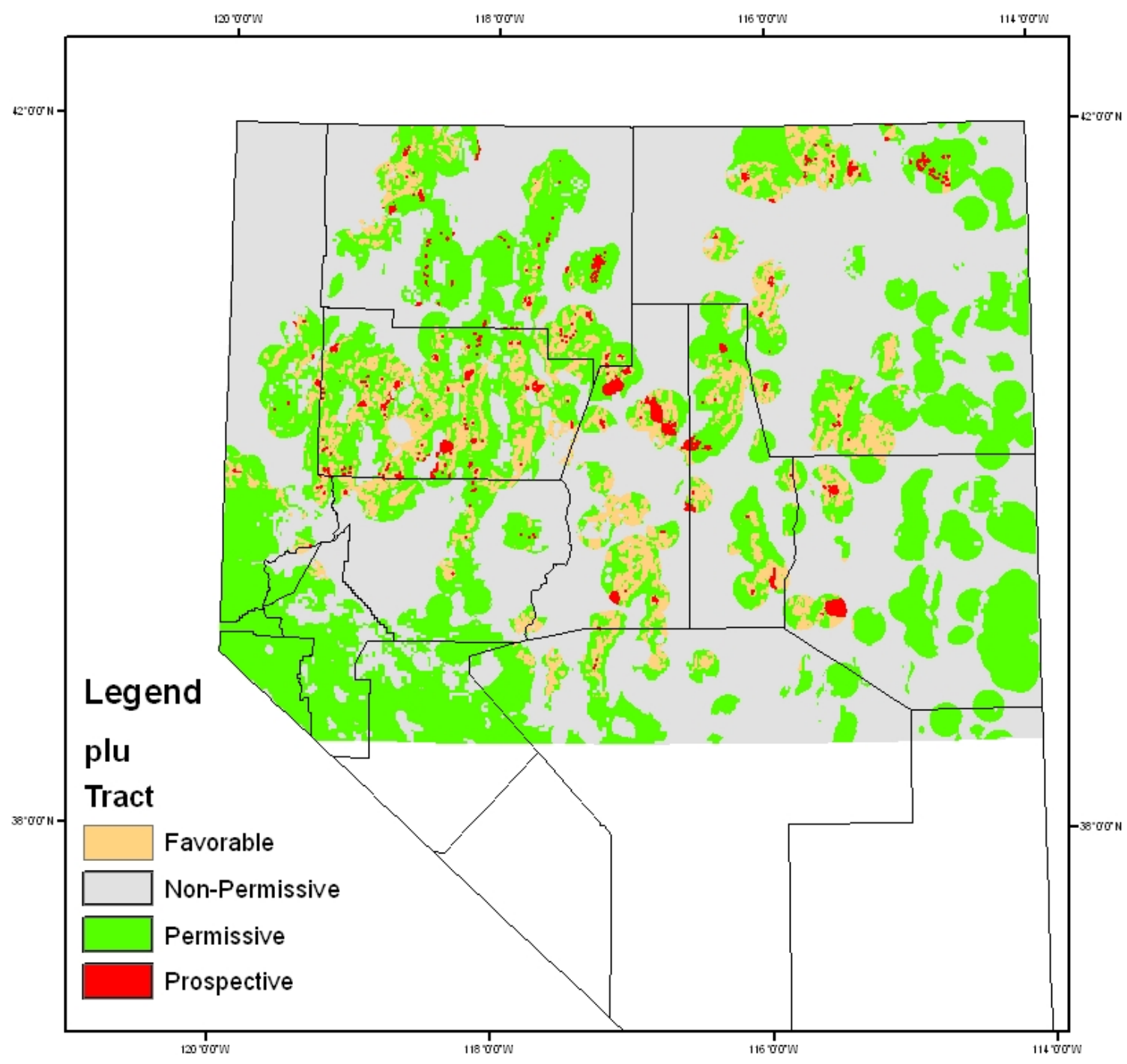

Figure 3. The plu tract and legend for pluton-related metal deposits. 


\section{SED}

Attributes of the ESRI raster grid for sedimentary rock-hosted Au-Ag metallic mineralresource assessment tract, sed, are displayed in table 4. WofE.dbf was created from ArcSDM and appended to the grid table. The plu tract and legend are displayed in figure 4.

Table 4. Attributes and descriptions for the SED grid with appended WofE.dbf

\begin{tabular}{|c|c|}
\hline Attribute & Attribute Description \\
\hline VALUE & Object ID. The internal feature number. \\
\hline COUNT & The count of grid cells with a particular value. \\
\hline ASSPAT & Presence or absence of predictor pattern arsenic anomaly. \\
\hline BANA & Presence or absence of predictor pattern $\mathrm{Ba} / \mathrm{Na}$ anomaly. \\
\hline LITHODVR & $\begin{array}{l}\text { Presence or absence of predictor pattern lithodiversity of the geologic } \\
\text { map of Nevada. }\end{array}$ \\
\hline GVBSLF & $\begin{array}{l}\text { Presence or absence of predictor pattern basement gravity lineaments, } \\
\text { reflecting abrupt lateral variations in the density of basement rocks. }\end{array}$ \\
\hline NE_LINEARS & $\begin{array}{l}\text { Presence or absence of predictor pattern NE (northeast) linear } \\
\text { features, representing two corridor regions that envelop the Crescent } \\
\text { Valley-Independence (CVIL) and Getchell (GLF) lineaments. }\end{array}$ \\
\hline NVGEOL51 & $\begin{array}{l}\text { Presence or absence of predictor pattern geologic units from the } \\
\text { geologic map of Nevada. }\end{array}$ \\
\hline PLUTONS & $\begin{array}{l}\text { Presence or absence of predictor pattern proximity to plutonic rocks } \\
\text { represented on the geologic map of Nevada. }\end{array}$ \\
\hline THSWIN & $\begin{array}{l}\text { Presence or absence of predictor pattern proximity to thrust faults } \\
\text { between upper- and lower-plate tectonic units and structural windows } \\
\text { of the Roberts Mountains thrust fault. }\end{array}$ \\
\hline TRRN & $\begin{array}{l}\text { Presence or absence of predictor pattern lithotectonic-terrane units, } \\
\text { representing geologic map units that, in combination, represent } \\
\text { specific allochthonous terranes in Nevada. }\end{array}$ \\
\hline AREA_SQM & $\begin{array}{l}\text { Arc-SDM calculation of area in meters squares of the unique } \\
\text { condition overlap. }\end{array}$ \\
\hline TRNGPOINTS & $\begin{array}{l}\text { Number of mineral training sites that fall within the unique condition } \\
\text { overlap. }\end{array}$ \\
\hline POST_PROB & $\begin{array}{l}\text { Posterior probability (the posterior logit converted to a probability), } \\
\text { calculated using Bayes' Rule. }\end{array}$ \\
\hline PSTPRBNRM & Normalized posterior probability. \\
\hline POST_LOGIT & Posterior logit (the sum of weights added to the prior logit). \\
\hline SUM_WEIGHT & $\begin{array}{l}\text { The sum of the weights }(\mathrm{W}+\text { and } \mathrm{W}-) \text { for each evidence map class } \\
\text { occurring in the unique condition. }\end{array}$ \\
\hline UNCERTAINT & $\begin{array}{l}\text { The uncertainty due to the calculation of weights (standard } \\
\text { deviation). }\end{array}$ \\
\hline MSNG_DATA & The uncertainty due to missing data (standard deviation). \\
\hline TOT_UNCRTY & $\begin{array}{l}\text { The combined uncertainty due to weights and due to missing data } \\
\text { (standard deviation). }\end{array}$ \\
\hline LRPOSTPROB & Posterior probability calculated using logistic regression. \\
\hline LRTVALUE & Logistic regression posterior probability Studentized-T value. \\
\hline LR_STD_DEV & Logistic regression posterior probability standard deviation. \\
\hline TRACT & $\begin{array}{l}\text { Mineral-resource assessment tract = nonpermissive, permissive, } \\
\text { favorable or prospective. }\end{array}$ \\
\hline
\end{tabular}




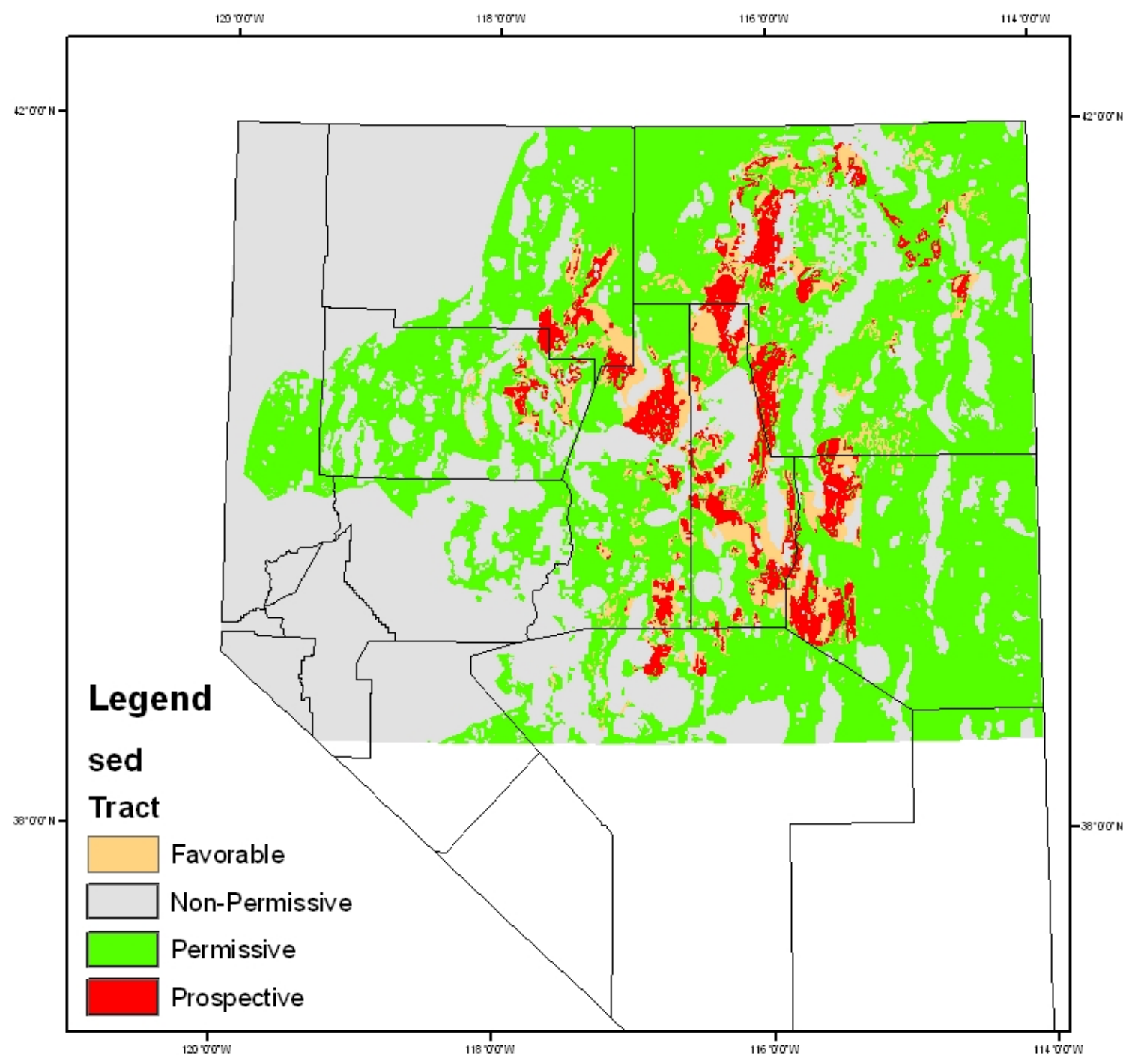

Figure 4. The sed tract and legend for sedimentary rock-hosted Au-Ag deposits. 


\section{Associated Tables}

A quantitative assessment of error and uncertainty related to WofE and WLR analysis and modeling is provided in the metadata in the form of four tables: 1) woe - spatial weights for each of the evidence maps 2) woevar - variance for the spatial weights 3) prb - results of pair-wise and overall tests for conditional independence 4) lrcoef - logistic regression coefficients.

The weights table, woe.dbf (table 5), records the bivariate spatial weights of the evidence maps and training sites, and provides the spatial weights of association (W+, $\mathrm{W}-$ ) measured between the training sites and the evidence maps, as well as the contrast (strength of the spatial association) and confidence (significance as measured by the studentized contrast, which is the contrast divided by its standard deviation).

Table 5. Attributes and descriptions for the WOE.dbf

\begin{tabular}{|l|l|}
\hline Attribute & Attribute Description \\
\hline EVIDENCE_T & Name of evidential theme (predictor map). \\
\hline W\# & Name of each field containing calculated weights by class. \\
\hline CONTRAST__ & The difference between the highest and smallest weight. \\
\hline CONFIDENCE & Contrast divided by its standard deviation = studentized contrast. \\
\hline
\end{tabular}

An important aspect of interpreting a favorability map is recognizing and quantifying the uncertainty inherent to the posterior probabilities. The two primary sources of uncertainty are: (1) the uncertainty due to variances in weight estimates (W+ and W-); and (2) the uncertainty due to one or more of the predictor maps having incomplete coverage (i.e., missing data). The weights variance table, woevar.dbf (table 6), records the variance for the spatial weights of association $(\mathrm{W}+, \mathrm{W}-)$ reported in the weights table, woe.dbf.

Table 6. Attributes and descriptions for the WOEVAR.dbf

\begin{tabular}{|l|l|}
\hline Attribute & Attribute Description \\
\hline EVIDENCE_T & Name of evidential theme (predictor map). \\
\hline V\# & $\begin{array}{l}\text { Standard deviations for the spatial weights of association in the } \\
\text { weights table, woe.dbf. }\end{array}$ \\
\hline
\end{tabular}

An important assumption made in WofE modeling is that the evidence layers are conditionally independent (CI) of one another with respect to the training sites (mineral deposits and occurrences). Evidence layer dependencies were tested by using a pairwise and an overall goodness-of-fit test, both of which make use of the observed versus the predicted number of observations (training sites). The pairwise test measures CI between all possible pairings of predictor maps (with respect to the training sites) by calculating 
the chi-square statistic for each map pair. The overall test is a comparison between the predicted number of training sites to the observed number (observed/predicted, referred to as the "CI ratio") and is a measure of the CI between all of the predictor maps in a model as a whole. The table of conditional independence of the posterior probabilities, prb.dbf, provides information on (1) pair-wise conditional independence between predictor maps, which appear within the matrix of the table, and (2) the overall measure of conditional independence (referred to as the "CI ratio"), which appears on the last line of table 7. Conditional independence is a significant factor when integrating the predictor maps to produce the favorability map.

In addition to the uncertainties due to weights variances and missing data, a relative certainty (variance) of the posterior probability can be calculated by dividing the posterior probability by its standard deviation, which in effect applies an informal Student t-test to determine whether the posterior probability is greater than zero for a given level of statistical significance (i.e., compared to a tabled t-value). The larger the tvalue over the critical tabled t-value cutoff, the greater the certainty of the posterior probability (i.e., the larger the posterior probability compared to its standard deviation). The relative certainty is often more useful than the weights variances or missing data uncertainties because it indicates the degree of confidence to which the posterior probabilities are meaningful, as opposed to being an artifact of chance effects or interactions. Care should be taken when interpreting the relative certainty because it is based on a normal distribution and sensitive to conditional independence.

Table 7. Attributes and descriptions for the PRB.dbf

\begin{tabular}{|l|l|}
\hline Attribute & Attribute Description \\
\hline ETHEME & Name of evidential theme (predictor map). \\
\hline CI RATIO & $\begin{array}{l}\text { Overall measure of condition independence }- \text { a chi-squared statistic } \\
\text { of observed training sites. }\end{array}$ \\
\hline
\end{tabular}

The logistic regression coefficients table, lrcoef.dbf, records the coefficient for a predictor map, which indicates its relative importance in determining the posterior probabilities of the favorability map (table 8 ).

Table 8. Attributes and descriptions for the LRCOEF.dbf

\begin{tabular}{|l|l|}
\hline Attribute & Attribute Description \\
\hline THEME_ID & Unique identifier for the predictor map. \\
\hline THEME & Predictor map name. \\
\hline COEFFICIEN & Logistic regression coefficient. \\
\hline
\end{tabular}


It is strongly recommended that the user consult the "Identification_Information/Description/Supplemental_Information" section of the metadata, as well as Chapter 2 (Wallace and others, 2004) for information about expert analysis, modeling techniques, and the vocabulary used in this mineral-resource assessment, as this information is essential for properly interpreting and applying the assessment tract maps.

\section{References}

Agterberg, F.P., Bonham-Carter, G.F., Wright, D.F., 1990, Statistical pattern integration for mineral exploration, in Gaál, G., and Merriam, D.F., eds., Computer Applications in Resource Estimation Prediction and Assessment of Metals and Petroleum: New York, Pergamon Press, p. 1-12.

Agterberg, F.P., Bonham-Carter, G.F., Cheng, Q., and Wright, D.F., 1993, Weights of evidence modeling and weighted logistic regression for mineral potential mapping, in Davis, J.C., and Herzfeld, U.C., eds., Computers in Geology, 25 Years of Progress: Oxford, England, Oxford University Press, p. 13-32.

Bonham-Carter, G.F., Agterberg, F.P., and Wright, D.F., 1989, Weights of evidence modelling: A new approach to mapping mineral potential, in Agterberg, F.P., and Bonham-Carter, G.F., eds., Statistical Applications in the Earth Science: Geological Survey of Canada, Paper 89-9, p. 171-183.

Bonham-Carter, G.F., 1994, Geographic Information Systems for Geoscientists: Modelling with GIS (Computer Methods in the Geosciences Volume 13): Tarrytown, New York, Pergamon Press/Elsevier Science Publications, 398 p.

Cox, D.P., Berger, B.R., Ludington, S., Moring, B.C., Sherlock, M.G., Singer, D.A., and Tingley, J.V., 1996, Delineation of mineral resource assessment tracts and estimation of number of undiscovered deposits in Nevada: Nevada Bureau of Mines and Geology Open-File Report 96-02, <http:/www.nbmg.unr.edu/dox/ofr962/c12.pdf>.

Folger, H.W., 2000, Analytical results and sample locations of reanalyzed NURE stream-sediment and soil samples for the Humboldt River Basin mineralenvironmental assessment, northern Nevada: Open-File Report 2000-421, U.S. Geological Survey, Denver, CO.

Hildenbrand, T.G., and Kucks, R.P., 1988, Total in, 1988, Total intensity magnetic anomaly map of Nevada: Nevada Bureau of Mines and Geology Map 93A, Nevada Bureau of Mines and Geology, Reno, NV.

Kemp, L.D., Bonham-Carter, G.F., Raines, G.L., and Looney, C.G., 2001, Arc-SDM; Arcview extension for spatial data modeling using weights of evidence, logistic 
regression, fuzzy logic, and neural networks analysis,

$<\underline{\text { http://ntserv.gis.nrcan.gc.ca/sdm/ }}$.

Lahren, M.M., Schweickert, R.A., and Connors K. A., unpub., Preliminary map of allochthonous tectonic units in Nevada and eastern California: U.S. Geological Survey map, scale 1:750,000.

McFaul, E.J., Mason, G.T., Jr., Ferguson, W.B, 2000, U.S. Geological Survey mineral databases; MRDS and MAS/MILS: U.S. Geological Survey Digital Data Series DDS0052, U.S. Geological Survey, Denver, CO.

Mihalasky, M.J., 2001, Mineral potential modelling of gold and silver mineralization in the Nevada Great Basin-A GIS-based analysis using weights of evidence: U.S. Geological Survey Open-File Report 01-291, 448 p., <http://geopubs.wr.usgs.gov/open-file/of01$\underline{291 />\text {. }}$

Mihalasky, M.J., and Wallace, A.R., 2004, Chapter 2: Assessment concepts and methodology, in Wallace, A.R., Ludington, S., Mihalasky, M.J., Peters, S.G., Theodore, T.G., Ponce, D.A., John, D.A., and Berger, B.R., Assessment of metallic mineral resources in the Humboldt River Basin, northern Nevada: U.S. Geological Survey Bulletin B-2218, 1 CD-ROM, <http://geopubs.wr.usgs.gov/bulletin/b2218/>.

Ponce, D.A., 1997, Gravity data of Nevada: U.S. Geological Survey Digital Data Series DDS-42, U.S. Geological Survey, Denver, CO.

Raines, G.L., 1999, Evaluation of weights of evidence to predict epithermal-gold deposits in the Great Basin of the western United States: Natural Resources Research, v. 8, p. 257-276.

Raines, G.L., and Mihalasky, M.J., 2002, A reconnaissance method for regional-scale mineral-resource assessment, based exclusively on geologic-map data: Natural Resources Research, v. 11, no. 4, p. 241-248.

Singer, D.A., 1993, Basic concepts in the three-part quantitative assessments of undiscovered mineral resources: Nonrenewable Resources, v. 2, p. 69-81.

Singer, D.A., ed., 1996, An analysis of Nevada's metal-bearing mineral resources: Nevada Bureau of Mines and Geology Open-File Report 96-2, $\leq$ http://www.nbmg.unr.edu/dox/ofr962/cover.pdf $>$.

Smith, S.M., 2000, National Geochemical Database - reformatted data from the National Uranium Resource Evaluation (NURE) Hydrogeochemical and Stream Sedimant Reconnaissance (HSSR): U.S. Geological Survey Open-File Report 97-0492, V. 1.20, <http://pubs.usgs.gov/of/1997/ofr-97-0492/>. 
Stewart, J.H., and Carlson, J.E., 1978, Geologic map of Nevada: U.S. Geological Survey and Nevada Bureau of Mines and Geology, Denver, CO.

Wallace, A.R., Ludington, S., Mihalasky, M.J., Peters, S.G., Theodore, T.G., Ponce, D.A., John, D.A., and Berger, B.R., 2004, Assessment of metallic mineral resources in the Humboldt River Basin, northern Nevada, with a section on PGE potential of the Humboldt mafic complex by M.L. Zientek, G.B. Sidder, and R.A. Zierenberg: U.S. Geological Survey Bulletin B-2218, 1 CD-ROM, $<$ http://geopubs.wr.usgs.gov/bulletin/b2218/>.

Wright, D.F., and Bonham-Carter, G.F., 1996, VHMS favourability mapping with GISbased integration models, Chisel Lake-Anderson Lake area, in Bonham-Carter, G.F., Galley, A. G., and Hall, G. E. M., eds., EXTECH I: A Multidisciplinary Approach to Massive Sulphide Research in the Rusty Lake-Snow Lake Greenstone Belts, Manitoba: Geological Survey of Canada Bulletin 426, p. 339-376, 387-401. 